\title{
Näkemyksiä Ison Britannian aikuiskasvatuksesta
}

Syksyllä 1981 oli Vapaan sivistystyön yhteisjärjestön vieraina 20 brittiläistä aikuiskasvattajaa. Viime keväänä suomalaiset olivat vastavierailulla. Ohjelman oli valmistanut National Institute of Adult Education 1) yhdessä British Councilin kanssa. Opintomatkaan sisältyi Lontoossa kahden päivän intensiivinen paneutuminen ajankohtaisiin aikuiskasvatuskysymyksiin, kolmen päivän tutustuminen käytännön aikuiskasvatustoimintaan pienryhmissä eri puolilla Isoa-Britanniaa sekä lopuksi Lontoossa päivien yhteenvetojakso.

Seuraavassa esitän vertailuja suomalaisesta ja brittiläisestä aikuiskasvatuksesta. $\mathrm{Ne}$ perustuvat enemmän tuntumuksiin kuin tosiasioihin.

Isossa Britanniassa ei ole varsinaista aikuiskasvatusjärjestelmää kuten ei Suomessakaan. Ilmeisesti britit ymmärtävät aikuiskasvatuksen vielä laajemmin kuin me, sillä siellä luetaan aikuiskasvatuksen piiriin osia nuoriso-, sosiaali- ja yhdyskuntatyöstä, samoinkuin kirjastojen, museoiden ja taidekeskusten toiminnas- ta. Osallistumistutkimusten mukaan suomalaisista aikuisista osallistuu vuoden aikana järjestettyihin aikuisopintoihin noin $26 \%$, kun taas vastaava prosentti Britanniassa on vain noin 12 . Tämä saattaa johtua siitä, että osanottajamaksut ovat korkeammat kuin meillä, ja niiden ennustetaan edelleen kohoavan. Osanottajamaksujen korkeus johtunee osittain siitä, että Isossa Britanniassa ei ole samanlaisia valtionapulakeja kuin meillä esim. vapaasta sivistystyöstä.

Brittiläiseen perinteeseen kuuluu laaja korkeakoulujen aikuisopetustarjonta, jota pyritään kehittämään mahdollisimman monipuoliseksi. Yleissivistävän aikuisopetuksen puolella on runsaasti erilaisia opiskelumahdollisuuksia, ja mahdollisesta päällekkäistarjonnasta ei välitetä. Yhteistoiminta paikallisella tasolla on ilmeisen elävää, valmistettiin yhteisiä esitteitä ja käynnistettiin erilaisia yhteisprojekteja.

Samalla tavoin kuin korkeakoulut ovat avanneet ovensa aikuisille, myös pai- kalliset koulut järjestävät aikuisopetusta osana varsinaista toimintaansa.

Brittiläisessä aikuiskasvatuksessa on vielä sellaista vapaaehtoisuuteen perustuvaa intoa, jota suomalaisesta opetustoimesta puuttuu. Voluntarismin traditio elää esim. laajassa lukutaitokampanjassa (ALBSU).

Aikuiskasvatuksen kehittämistä varten perustettiin 1977 kuudeksi vuodeksi opetus- ja tiedeministeriön avuksi Advisory Council for Adult and Continuing Education, jolla on suurinpiirtein samanlaiset tehtävät ja kokoonpano kuin meidän kehittämisorganisaatiollamme, mutta britit ovat olleet tehokkaampia kuin me, sillä ACACE:n projektiryhmät ovat tuottaneet yli 30 erilaista muistiota, laajempaa kehittämisehdotusta, tutkimusta jne. Käytännön kehittämistoiminnasta on ensin tehty poliittinen linjapäätös ja päätöksen käytännön toteuttaminen tarvittavine rahoineen on annettu asiantuntijoille. Kehittämistoiminnassa on priorisoitu työttömille tarkoitetun opetuksen järjestäminen. 
Brittiläiset aikuiskasvattajat kokevatkin, että aikuiskasvatuksen uudistaminen ei kuulu yhteiskunnan kehittämisen painopistealueisiin kuten työllisyyden hoito tai sosiaali- ja koulutoimen kehittäminen. Aikuiskasvatuksen puolesta puhumisella vaaleissa ei saa ääniä.

Lopuksi erään britin toteamus tietoyhteiskunnan vaaroista. Sirpaletieto lisääntyy jatkuvasti, mutta vain harvat kykenevät arvioimaan tiedon validiteettia. Vaarana onkin että sivistys muuttuu pelkäksi ulkoiseksi kohteliaisuudeksi.

\section{Ison-Britannian aikuiskasvatusta käsittelevää kirjallisuutta:}

Derek Legge. The education of adults in Britain. The Open University Press. Milton Keynes 1982 Arthur Stock. Adult Education in Great Britain. NIAE 1978

Bernard Jenning. Adult Education in Europe: United Kingdom. European Centre for Leisure and Education. Studies and docoment. No 9/1981

Colin Titmus. Strategies for Adult Education. Practices in Western Europe. The Open University Press 1981

Advisory Council for Adult and Continuing Education (ACACE) on julkaissut mm. seuraavat kirjat: - Continuing Education: from Policies to prac- tice. Leicester 1982. Sisältää neuvoston esitykset aikuisten elinikäisen kasvatusjärjestelmän kehittämiseksi.

- Adults, Their educational Experience and Needs. Leicester 1982. Valtakunnallisen osallistumistutkimuksen tulokset. Vastaa meidän Tilastokeskuksen tutkimusta Aikuiskoulutuksen osallistuminen (Nro 92).

- Proposals. The Case for a national Development Body for Continuing Education in England and Wales. Leicester 1982. Tämä 12-sivuinen kirjanen vastaa osittain meidän aikuiskoulutuksen kehittämisen yleissuunnitelmaa ja sisältää myös toimenpide-ehdotuksia elinikäisen kasvatuksen järjestelmästä.

ACACEn julkaisuja voi tilata osoitteesta: ACACE, 19b De Montfort Street, Leicester JE1 7GE, Great Britain. Samasta osoitteesta saa myös National Institute of Adult Continuing Education (NIACE) toimittamia julkaisuja ja molempien organisaatioiden julkaisuluetteloita.

Avointa yliopistoa koskevia julkaisuja saa The Open University, Walton Hall, Milton Keynes MK7 6AA, Great Britain.

Adult Literacy \& Basic Skill Unit (ALBSU) lienee mielenkiintoisin kehittämisprojekti Isossa-Britanniassa. Tavoitteena luku- ja kirjoitustaidottomien aikuisten opettaminen. Tietoa saa ALBSU, Kingsbourne House, 229/231 High Holborn, London WC1V 7DA, Great Britain.

Seuraavat hakemistot antavat yleistietoja:

- Year book af adult education 1982-83, NIAE 1982

- Directory of adult education organizations in Europe, European bureau of adult education, Nieuweweg 4, P.O. Box 367, 3800 AJ Amersfoort, The Netherlands. 